\section{Editorial}

Check for updates

\section{OPEN ACCESS}

Received: Jan 1, 2020

Accepted: Jan 2, 2020

Correspondence to

Jung-Won Park, MD, PhD

Allergy Asthma Center, Severance Hospital,

Yonsei University College of Medicine, 50-1

Yonsei-ro, Seodaemun-gu, Seoul 03722, Korea.

Tel: +82-2-2228-1961

Fax: +82-2-362-8647

E-mail: parkjw@yuhs.ac

Copyright (c) 2020 The Korean Academy of Asthma, Allergy and Clinical Immunology .

The Korean Academy of Pediatric Allergy and

Respiratory Disease

This is an Open Access article distributed under the terms of the Creative Commons Attribution Non-Commercial License (https:// creativecommons.org/licenses/by-nc/4.0/) which permits unrestricted non-commercial use, distribution, and reproduction in any medium, provided the original work is properly cited.

ORCID iDs

Jung-Won Park (D)

https://orcid.org/0000-0003-0249-8749

Disclosure

There are no financial or other issues that might lead to conflict of interests.

\title{
Revised Pollen Calendar in Korea
}

\section{Jung-Won Park $\mathbb{1}^{*}$}

Allergy Asthma Center, Severance Hospital, Yonsei University College of Medicine, Seoul, Korea

- See the article "Allergenic Pollen Calendar in Korea Based on Probability Distribution Models and Up-to-Date Observations" in volume 12 on page 259.

Pollens are one of the most important causes of respiratory allergy including allergic rhinoconjunctivitis, and can even cause food allergies. ${ }^{1-3}$ Recently, the prevalence of both pollinosis and pollen-food allergy syndrome has increased in Korea, which may reflect climate changes ${ }^{4}$ as well as increases in the growth of tree stocks in Korean forests. From 2005 to 2015, the growth of tree stocks doubled from 79.2 to $146 \mathrm{~m}^{2} / \mathrm{ha},{ }^{5}$ and the planting density of trees in the order Fagales (including oak, birch, and alder) increased steadily, in contrast to those of pines. The types of pollens responsible for allergic reactions differ geographically, as the major inhabitant trees, grasses, and weeds markedly differ from region to region. To be termed a "causative pollen," several conditions must be met. In the 1930s, August Thommen ${ }^{6}$ suggested a list of postulates for causative pollens, which is still used today. First, the pollen must contain allergens to induce pollinosis, as it is not true that every type of pollen is allergenic. Secondly, the pollen should be windborne. Although pine tree pollen is windborne and abundantly distributed in Korea, its allergenicity is minimal and does not induce clinical symptoms. Thirdly, the pollen must be produced in sufficiently large quantities to cause symptoms. Fourthly, the pollen must be sufficiently buoyant to be carried considerable distances. Trees that distribute windborne pollen produce large amounts of pollen with buoyant shapes. For example, a single birch tree produces about 5.5 billion pollen grains annually, whereas an oak produces 0.6 billion pollen grains. Finally, the plant producing the pollen must be abundantly distributed. Species of trees that meet these criteria are limited in each country, and thus a pollen calendar should focus on tree species that meet Thommen's postulates.

In this issue of the Allergy, Asthma \& Immunology Research, Shin et al. 7 presents a current pollen calendar in South Korea based on pollen counts from 2007 to 2017. It should be noted that this group published the pollen calendar collected from 1997 to 2009. ${ }^{8}$ Based on this new calendar, we can compare the changes in allergy-causing pollen counts as a result of climate change and the growing stock of trees and weeds, especially Fagales, Japanese cedar (Cryptomeria japonica), and Humulus japonicus, throughout Korea. This study showed marked annual differences in pollen counts and length of pollen seasons in this country, which are already well-known findings in other countries. ${ }^{6}$ These differences help explain why the annual severity of pollinosis differs greatly, and support the need for long-term studies to evaluate the effects of climate and ecological changes, with or without human interference, on pollinosis. Short-term studies may not have a sufficient power to overcome the compounded effects of the annual differences in pollen counts.

Interestingly, regional differences in pollen counts are significant, even in a small country like Korea. Southern provinces have different patterns of pollen counts. Previously, Japanese cedar 
pollen was found on Jeju Island exclusively, but this new calendar in this issue shows that a significant number of Japanese cedar pollen grains were also found in the southern provinces of Kwangju, Busan, and Jeonju, in addition to Jeju Island. Such differences may reflect the latitudinal elevation of plant hardiness zones for Japanese cedar. Another interesting feature is that the pollen count of alder, which belongs to the birch family (Betulaceae), is higher than that of birch in the southern cities such as Busan, Gwangju and Jeonju. The pollen calendar for the Gangneung area is also unique. Birch and hazelnut pollen counts are significantly higher in this area, as both belong to the Betulaceae family and favor northern temperate and boreal climates. Pollen counts for weeds and grasses do not differ from those described in previous studies. The weeds (H. japonicus, mugwort, and ragweed) are important causes of pollinosis in Korea, with $H$. japonicus responsible for the highest number of cases. Recent studies published in Korea demonstrated that the major causes of pollen-food allergy syndrome are due to group 1 major allergens of trees belonging to the order Fagales. However, mugwort-related pollenfood allergy syndrome, via lipid transfer protein allergen, has been reported in both China and Korea, ${ }^{9,10}$ suggesting an important role of mugwort pollen in this syndrome in East Asia.

In conclusion, Shin et al. ${ }^{7}$ study describes the pollens responsible for allergic reactions in Korea in detail, allowing better interpretations of skin prick test and specific immunoglobulin E results (considering actual levels of pollen exposure) and reasonable applications of allergen immunotherapy in affected individuals. Furthermore, this study describes the effects of climate and ecological changes on the significant differences in pollen counts, with or without human interference, in Korea.

\section{REFERENCES}

1. Kim M, Ahn Y, Yoo Y, Kim DK, Yang HJ, Park HS, et al. Clinical manifestations and risk factors of anaphylaxis in pollen-food allergy syndrome. Yonsei Med J 2019;60:960-8. PUBMED | CROSSREF

2. Lee SC, Kim SR, Park KH, Lee JH, Park JW. Clinical features and culprit food allergens of Korean adult food allergy patients: a cross-sectional single-institute study. Allergy Asthma Immunol Res 2019;11:723-35. PUBMED | CROSSREF

3. Kong N, Kim S, Lee SC, Park KH, Lee JH, Park JW. Subcutaneous immunotherapy in patients with Fagales pollen-induced oral allergy syndrome. Yonsei Med J 2019;60:389-94. PUBMED | CROSSREF

4. D'Amato G, Pawankar R, Vitale C, Lanza M, Molino A, Stanziola A, et al. Climate change and air pollution: effects on respiratory allergy. Allergy Asthma Immunol Res 2016;8:391-5. PUBMED | CROSSREF

5. Korea Forest Service. Statistical yearbook of forestry 2016. Daejeon: Korea Forest Service; 2016.

6. Weber RW. Aerobiology of outdoor allergens. In: Adkinson NF Jr, Bochner BS, Burks AW, Busse WW, Holgate ST, Lemanske RF, et al., editors. Middleton's allergy: principle and practice. 8th ed. Philadelphia (PA): Elsevier Saunders; 2014. 430-52.

7. Shin JY, Han MJ, Cho C, Kim KR, Ha JC, Oh JW. Allergenic pollen calendar in Korea based on probability distribution models and up-to-date observations. Allergy Asthma Immunol Res 2020;12:259-73. CROSSREF

8. Oh JW, Lee HB, Kang IJ, Kim SW, Park KS, Kook MH, et al. The revised edition of Korean calendar for allergenic pollens. Allergy Asthma Immunol Res 2012;4:5-11. PUBMED | CROSSREF

9. Kim MA, Kim DK, Yang HJ, Yoo Y, Ahn Y, Park HS, et al. Pollen-food allergy syndrome in Korean pollinosis patients: a nationwide survey. Allergy Asthma Immunol Res 2018;10:648-61. PUBMED | CROSSREF

10. Deng S, Yin J. Mugwort pollen-related food allergy: lipid transfer protein sensitization and correlation with the severity of allergic reactions in a Chinese population. Allergy Asthma Immunol Res 2019;11:116-28. PUBMED | CROSSREF 